\title{
Impact of Incentives on the Job Performance of Employees Working in Textile Industries of District Kohat
}

\author{
Ishtiaq Hussain $^{1}$, Nabi Bux Jumani ${ }^{2}$, Sarfraz Ahmad ${ }^{3}$
}

\begin{abstract}
The study was focused to find the impact of the incentives on the job performance of the employees working in the textile industries particularly conducted to identify the financial \& non-financial incentives used for the betterment of textile employees. This study also compared the significance of incentives between Kohat Textile Mills and Janana Demaluchu Textile Mills in district Kohat. Population of the study constituted all the employees working in the Textile Mills situated in district Kohat. The study was delimited to the two Textiles Mills of district Kohat i.e., Kohat Textile Mills and Janana Demaluchu Textile Mills. 60 respondents, having age between 20 to 50 years, were selected using stratified sampling technique from two selected textile mills (30 from Kohat Textile Mills and 30 from Janana Demaluchu Textile Mills). A self-made questionnaire was used as research instrument for the collection of the information from the employees working in sampled textile mills. After collection of the data, it was tabulated and analyzed by using t-test for finding the significance between two mills at alpha level of 0.05 value. It was concluded that salary packages, overtime payment and bonus were more attractive financial rewards as compared to the non-financial rewards like free education of the children, recreational activities, and retirement benefits which were considered as more necessary for the employees' satisfaction into their lives.
\end{abstract}

Keywords: Yearnings, Financial, Non-financial, Employees, Packages, Overtime

\section{Introduction}

Textile is a fare arranged industry of Pakistan. Throughout the budgetary year 2008-09, a large portion of its fare things for instance yarn, fabric, readymade articles of clothing, towel, and bunk cloth have stayed under global aggressive weight. Its experience sum trades had declined from 66 Percent in FY

\footnotetext{
${ }^{1}$ Associate Professor, Institute of Education \& Research, Kohat University of Science \& Technology (KUST) Kohat Email: dr.ishtiaq@kust.edu.pk

${ }^{2}$ Professor of Education/ Director, Directorate of Distance Education, IIUI

Email: nb.jumani@iiu.edu.pk

${ }^{3}$ Lecturer, Department of Education \& Psychology, Kohat University of Science \& Technology (KUST) Kohat Email: sarfraz206@gmail.com
} 
2004-05 to 54 Percent in the FY 2008-09 (Ministry of Finance, 2009). There are different national and global variables influencing the execution of the material part. Vital variables in the residential environment influencing the material segment incorporate: quick expand in the expense of creation, vigor emergency, war against terrorism, and high investment rates and so forth. While worldwide variables incorporate: worldwide financial emergency, expand in worldwide supply of material items, antidumping obligations on Pakistani material items, and exchange restraints.

The idea of worker fulfillment is a multi-dimensional and bury disciplinary term that has been pulled in the consideration of analysts and experts from diverse teaches, for example, brain research, human asset administration, organizational conduct, TQM thus stronghold. In literary works there are an expansive number of studies that dissect the term from numerous alternate points of view and its association with different organizational variables (Lund, 2003). However there is no general meaning of worker fulfillment that uncovered all these sizes in the meantime (García-Bernal, Gargallo-Castel, Marzo-Navarro \& Rivera-Torres, 2005).

Naturally, the routines for generation and work association in this industry remain heterogeneous. A substantial number of ladies in the piece of clothing industry are imperceptible as home-based representatives, getting work from the foremen and subcontractors, frequently having little association with the main executor. Much of their work comprises of sewing, bind sewing and weaving. Except for expansive units, wages are piece-evaluated. Despite the fact that approach recommends that all article of clothing units be enrolled and adjust to authoritative solutions, there is extensive scale avoidance. The troubling characteristic is the consistent trepidation of conclusion of units. Studies uncover that ladies additionally get more level wages than men actually when they do comparable work. A spin-off of home-based work is the high rate of youngster labour in this industry (Cranny, Smith \& Stone, 1992).

\subsection{Objectives of the Study}

Objectives of the study were:

1. To find the impact of financial incentives on the job performance of the employees working in textiles mills.

2. To find the impact of non-financial incentives on the job performance of the employees working in textiles mills.

\section{Literature Review}

Development of human assets is obviously the first essential for both distinct victory and aggregate national advancement (Azhar, 2004). Human asset 
improvement distinguishes the central necessity to use the human assets completely and identifies instruction to the requirements and yearnings of the individuals. It strives to carry the profits of training to the impeded classes of the populace, to make an atmosphere of control and diligent work and to support in the interest for instructive development and change of value. Assuming that a nation is to development, the limits of men and ladies the human assets (physical, mental and profound) are to be produced broadly (Zaidi, 2006).

Underpinned by Rehman (2008) preparation makes the ground realities helpful for change in the association (in positive course) so the forward looking associations view trainings as an esteemed venture. It will be a profoundly imaginative thought if exchange unions are included in laborer's quality expansion through on employment trainings.

The thought of worker fulfillment has been a center for exploration and practice throughout the previous two decades specifically (Greasley, Bryman, Dainty, Price, Soetanto \& King, 2005) and recognized to be a discriminating issue for organizational execution. Various researchers and administration "masters" focused on the criticalness of worker fulfillment and its impacts on organizational execution to the extent that client fulfillment (Chen, et. al., 2006).

Fashoyin (1997) opined that the representatives in aggressive financial environment get to be more vital executor in assembling all elements of creation towards accomplishment of an intense preference. In any case this is conceivable by propelled workforce. Furthermore cause of the workforce to confer itself to work and support continuous and viable operations further rely on fulfillment of workers.

World Bank (1991) in its report inferred that better health and sustenance rise workers "benefit diminish the amount of days they are sick, and drag out their potential working lives. In Sierra Leone, a 10 percent increment in calories in-take of homestead workers expending 1500 calories a day raised their yield by 5 percent. Comparative effects have been found around Kenyan street development workers. By lessening horribleness and debility, the jungle fever annihilation program in Sri Lanka in the 1940s accelerated a ten percent climb in wages.

An investigation of Basta, Soekirman, Karyadi and Scrimshaw (1979) on the elastic manor representatives in Indonesia uncovered that medicine of pallid workers with iron tablets for a time of 60 days brought about an increment in profit by 15 to 20 percent and the for every capita expense of these tablets was $\$$ 0.08 .

As per Asif (2007) we do know beyond any doubt that their requests for better instruction and employments surpass their chances and that they are the 
most essential accomplice in the nation's populace. We likewise realize that little has been carried out by the state to decrease the sexual orientation disparities confronted by the following era. There is much scope for further research around the nation to investigate how expanded levels of ladies' job in the flow grown-up populace has affected the female youth, their desires, and their chances for paid work. It is safe to say that we are nearly approaching social conversion without distinguishing the signs? Pakistan is experiencing a large number of the monetary and social progressions encountered by its neighbors in the locale. Lamentably, it doesn't profit from as much research to translate what is going on. While we do have some fundamental data about ladies and paid work, and where progressions are occurring, much work of our own is left before we can guarantee information about the field.

A study done by Tausif (2012), who explained the relationship between non-financial incentives (having focus on job autonomy, job enrichment and promotion) and job satisfaction in the educational field of Pakistan. He has identified that the persons having more age were more satisfied than younger ones. Another research identified that non-financial rewards are more beneficial for the health workers which become cause of their satisfaction. A study done by the Group (2011) stated that non-financial rewards increase the productivity and enhance the profit rate of the organization. An overall reward program gives a good perception about the non-financial rewards which was basically dependent on the fairness of the different programs with some incentives as a reward. According to "policy on employee welfare" (Teti \& Andriotto, 2013), the management is responsible for training and supervising employees on safe procedures and healthcare, providing information on safety hazards and providing safety equipment.

\subsection{Research Design}

\section{Research Methodology}

Research was descriptive in nature, in which mixed method approach was used. Data was collected with the help and cooperation of a friend who had been working in Kohat textile mill for the last 15 years.

\subsection{Population}

All the employees (total 2103) working in the Textile Mills situated in district Kohat were population of the study.

\subsection{Sample and Sampling Technique}

60 respondents, having age between 20 to 50 years, were selected using stratified sampling technique from two selected textile mills (30 from Kohat 
Textile Mills and 30 from Janana Demaluchu Textile Mills) as sample of the study.

\subsection{Delimitation of the Study}

The study was delimited to the two Textiles Mills of district Kohat i.e., Kohat Textile Mills and Janana Demaluchu Textile Mills.

\subsection{Research Instrument}

A self-made questionnaire was used as research instrument for the collection of the data from the employees working in sampled textile mills. The questionnaire was having two parts i.e. financial and non-financial rewards.

\subsection{Validity of Research Instrument}

The questionnaire was sent to experts for validation and for their expert opinion and advice. Their suggestions and expert opinions were incorporated and some changes and improvements were made in the questionnaire.

\subsection{Reliability of Research Instrument}

To compute the reliability and internal consistency of the research instrument. Data collected through questionnaires from 20 respondents from the Babri Cotton mill, Kohat was recorded and analyzed using SPSS 16.0 (a pilot study). The results are as follows:

$$
\begin{gathered}
\text { Reliability Statistics of the Research Instrument } \\
\text { Cronbach's Alpha N of Items }
\end{gathered}
$$

$\mathrm{N}$ of Items

.990 30

\subsection{Data Collection}

The research instrument which was used for the data collection was a questionnaire, which was framed after analysis of the different research studies conducted to find the job performance of the industrial employees. Data were collected through personal visits of researcher.

\section{Data Analysis and Interpretation}

The collected data were analyzed dimension wise using SPSS 16.0 Dimensions of the questionnaire were as under;

i. Financial Rewards

ii. Non-Financial Rewards

\section{Provision of Financial Rewards in Kohat Textile Mill}


Table No 4.1

Analysis of Financial Incentives in Kohat Textile Mill, Kohat

\begin{tabular}{|c|c|c|c|c|c|c|c|c|}
\hline Statements & SA & $\mathrm{A}$ & & $\mathrm{N}$ & $\mathrm{D}$ & & SD & \\
\hline \multirow[t]{2}{*}{ Salary is given in time every month. } & 3 & 13 & & 3 & 6 & & 5 & \\
\hline & $10 \%$ & 43.3 & $\%$ & $10 \%$ & 20 & $\%$ & 16.6 & $\%$ \\
\hline \multirow[t]{2}{*}{ Bonus is given to the employees regularly. } & 5 & 16 & & 4 & 3 & & 2 & \\
\hline & $16.6 \%$ & 53.3 & $\%$ & $13.3 \%$ & 10 & $\%$ & 6.6 & $\%$ \\
\hline \multirow[t]{2}{*}{ Advance salaries are easily disbursed. } & 2 & 7 & & 9 & 6 & & 6 & \\
\hline & $6.6 \%$ & 23.3 & $\%$ & $30 \%$ & 20 & $\%$ & 20 & $\%$ \\
\hline \multirow{2}{*}{$\begin{array}{l}\text { Yearly increment is given to the employees } \\
\text { as per government policy. }\end{array}$} & 1 & 3 & & 6 & 17 & & 3 & \\
\hline & $3.3 \%$ & 10 & $\%$ & $20 \%$ & 56.6 & $\%$ & 10 & $\%$ \\
\hline \multirow{2}{*}{$\begin{array}{l}\text { Marriage allowance is given to the } \\
\text { employees. }\end{array}$} & 2 & 5 & & 8 & 6 & & 9 & \\
\hline & $6.6 \%$ & 16.6 & $\%$ & $26.6 \%$ & 20 & $\%$ & 30 & $\%$ \\
\hline \multirow{2}{*}{$\begin{array}{l}\text { Money is provided to the employees for the } \\
\text { marriage of their children. }\end{array}$} & 5 & 11 & & 2 & 4 & & 8 & \\
\hline & $16.6 \%$ & 36.6 & $\%$ & $6.6 \%$ & 13.3 & $\%$ & 26.6 & $\%$ \\
\hline \multirow{2}{*}{$\begin{array}{l}\text { Appropriate compensation is provided in } \\
\text { case of disability due to accidents. }\end{array}$} & 3 & 2 & & 9 & 7 & & 9 & \\
\hline & $10 \%$ & 6.6 & $\%$ & $30 \%$ & 23.3 & $\%$ & 30 & $\%$ \\
\hline \multirow{2}{*}{$\begin{array}{l}\text { Educational expenditures are provided for } \\
\text { the admission of employees children. }\end{array}$} & 13 & 8 & & 3 & 5 & & 1 & \\
\hline & $43.3 \%$ & 26.6 & $\%$ & $10 \%$ & 16.6 & $\%$ & 3.3 & $\%$ \\
\hline \multirow{2}{*}{$\begin{array}{l}\text { Employees are provided handsome amount } \\
\text { as commutation at retirement. }\end{array}$} & 4 & 6 & & 2 & 7 & & 11 & \\
\hline & $13.3 \%$ & 20 & $\%$ & $6.6 \%$ & 23.3 & $\%$ & 36.6 & $\%$ \\
\hline \multirow{2}{*}{$\begin{array}{l}\text { Remuneration is given according to the job } \\
\text { level. }\end{array}$} & 5 & 15 & & 3 & 4 & & 3 & \\
\hline & $16.6 \%$ & 50 & $\%$ & $10 \%$ & $\begin{array}{r}13.3 \\
3\end{array}$ & $\%$ & $\begin{array}{r}10.0 \\
0\end{array}$ & $\%$ \\
\hline
\end{tabular}

Table shows that most of the people agree that salary is given to the employees each month timely but sometimes it gets delay due to not availability of the staff or some technical faults of the accounts system (43.33\%). Employees are given annual bonus depending on the performance of the mill $(53.33 \%)$. Advance salaries are disbursed but most of the people do not agree on this situation (30\%). Employees are mostly at their daily wages and do not have concern with the annual increment (56.67\%). Marriage allowance is given but not possible for the whole employees $(30 \%)$. Although, financial aid is given to the employees in respect of their children marriage expenses $(36.67 \%)$. Appropriate compensation is not given to the employees in case of any disability $(30 \%)$. Kohat Textile mill takes care about the education of the employees 
children $(43.33 \%)$. At the end of the service employees do not get handsome amount to run their remaining life (36.67\%). Overall, remuneration is as per level of the employees' capabilities (50\%). It has also been explained through the following Graph (Figure No 1).

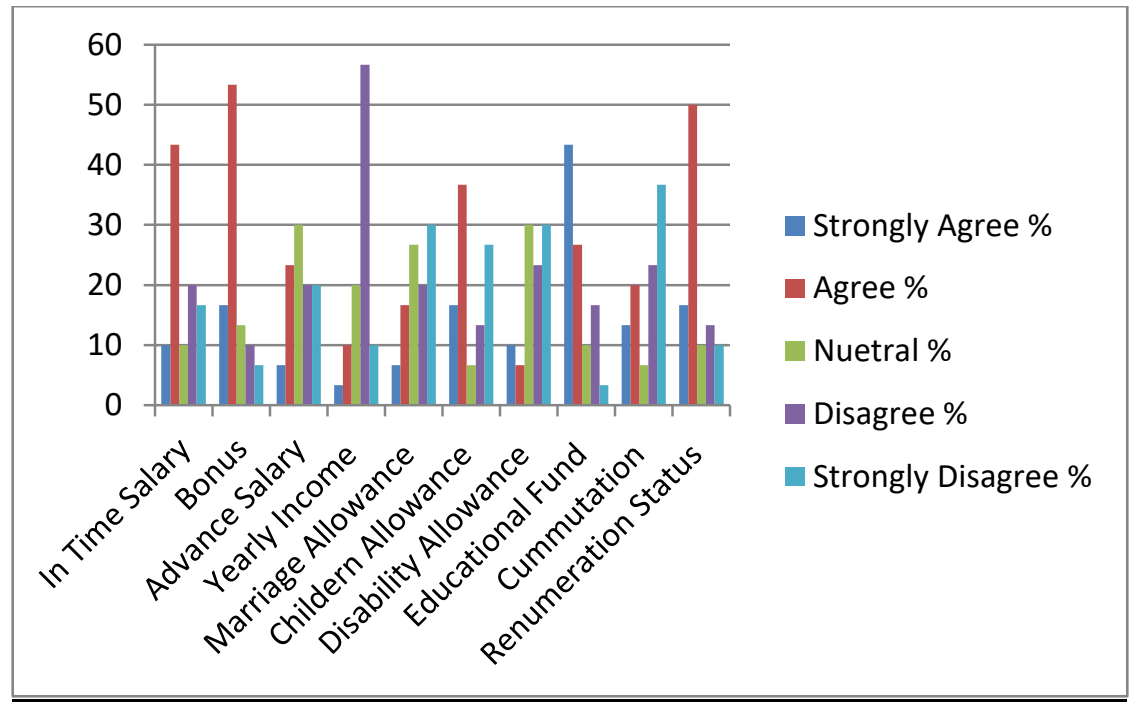

Figure 1 Graph of Financial Rewards in Kohat Textile Mill, Kohat 


\subsection{Provision of Non-Financial Rewards in Kohat Textile Mill}

Table No 4.2

Analysis of Non-Financial Incentives in Kohat Textile Mill, Kohat

\begin{tabular}{|c|c|c|c|c|c|c|c|c|c|}
\hline Statements & SA & & $\mathrm{A}$ & & $\mathrm{N}$ & & $\mathrm{D}$ & $\mathrm{SD}$ & \\
\hline \multirow[t]{2}{*}{ Mill has its own hospital. } & 1 & & 2 & & 12 & & 9 & 6 & \\
\hline & 3.3 & $\%$ & 6.6 & $\%$ & 40 & $\%$ & 30 & 20 & $\%$ \\
\hline \multirow{2}{*}{$\begin{array}{l}\text { Mill has its collaboration with any } \\
\text { hospital. }\end{array}$} & 9 & & 11 & & 4 & & 5 & 1 & \\
\hline & 30 & $\%$ & 36.6 & $\%$ & 13.3 & $\%$ & 16.6 & 3.3 & $\%$ \\
\hline \multirow{2}{*}{$\begin{array}{l}\text { Transportation facility is provided to the } \\
\text { employees. }\end{array}$} & 3 & & 7 & & 13 & & 2 & 5 & \\
\hline & 10 & $\%$ & 23.3 & $\%$ & 43.3 & $\%$ & 6.6 & 16.6 & $\%$ \\
\hline \multirow{2}{*}{$\begin{array}{l}\text { Appreciation certificates are given away } \\
\text { to the efficient employees annually. }\end{array}$} & 1 & & 5 & & 7 & & 15 & 2 & \\
\hline & 3.3 & $\%$ & 16.6 & $\%$ & 23.3 & $\%$ & 50 & 6.6 & $\%$ \\
\hline \multirow[t]{2}{*}{ Hajj quota is available for the employees. } & 1 & & 4 & & 9 & & 7 & 9 & \\
\hline & 3.3 & $\%$ & 13.3 & $\%$ & 30 & $\%$ & 23.3 & 30 & $\%$ \\
\hline \multirow{2}{*}{$\begin{array}{l}\text { First aid facilities are provided at work } \\
\text { place. }\end{array}$} & 9 & & 12 & & 1 & & 2 & 6 & \\
\hline & 30 & $\%$ & 40 & $\%$ & 3.3 & $\%$ & 6.6 & 20 & $\%$ \\
\hline \multirow{2}{*}{$\begin{array}{l}\text { Regular medical checkup is done of the } \\
\text { employees and their families. }\end{array}$} & 1 & & 4 & & 7 & & 9 & 9 & \\
\hline & 3.3 & $\%$ & 13.3 & $\%$ & 23.3 & $\%$ & 30 & 30 & $\%$ \\
\hline \multirow[t]{2}{*}{ Hire and fire policy is not satisfactory. } & 11 & & 7 & & 5 & & 3 & 4 & \\
\hline & 36.6 & $\%$ & 23.3 & $\%$ & 16.6 & $\%$ & 10 & 13.3 & $\%$ \\
\hline \multirow{4}{*}{$\begin{array}{l}\text { Basic utilities shops (Cobbler, washer } \\
\text { man, hairdresser and utility stores) are } \\
\text { provided to the employees. } \\
\text { Proper security arrangement is made to } \\
\text { secure the lives/property of the } \\
\text { employees. }\end{array}$} & 2 & & 3 & & 7 & & 7 & 11 & \\
\hline & 6.6 & $\%$ & 10 & $\%$ & 23.3 & $\%$ & 23.3 & 36.6 & $\%$ \\
\hline & 11 & & 13 & & 3 & & 2 & 1 & \\
\hline & 36.6 & $\%$ & 43.3 & $\%$ & 10 & $\%$ & 6.6 & 3.33 & $\%$ \\
\hline
\end{tabular}

Table shows the results regarding Non-Financial rewards given in Kohat Textile Mill. Mill has no such particular Hospital which is called on the name of Kohat Textile Mill (40\%). Although, this Mill has collaboration with the other hospitals, where, treatment is allowed for the employees $(36.67 \%)$. Transport facility is available but not as regular as we consider (43.33\%). Appreciation certificates are given only to the key posts but not given to the lower levels but not been given to other employees (50\%). Hajj Quota is not available for the employees (30\%). First Aid facilities are available in case of any emergency $(40 \%)$. Regular medical checkup is not being taken of the employees $(30 \%)$ and also there is no such free facility for their families. Hiring facility is also not 
satisfactory $(36.67 \%)$. Kohat Textile Mill has not provided all basic facilities to the employees including Cobbler, washer man, Hairdresser and utility stores inside the vicinity of the Mill (36.67\%). This Mill has good security arrangements because of having retired persons of the defense forces (Army and Air Force) (43.33\%). Overall analysis of the Non-Financial rewards has been explained through the following Graph (Figure No 2).

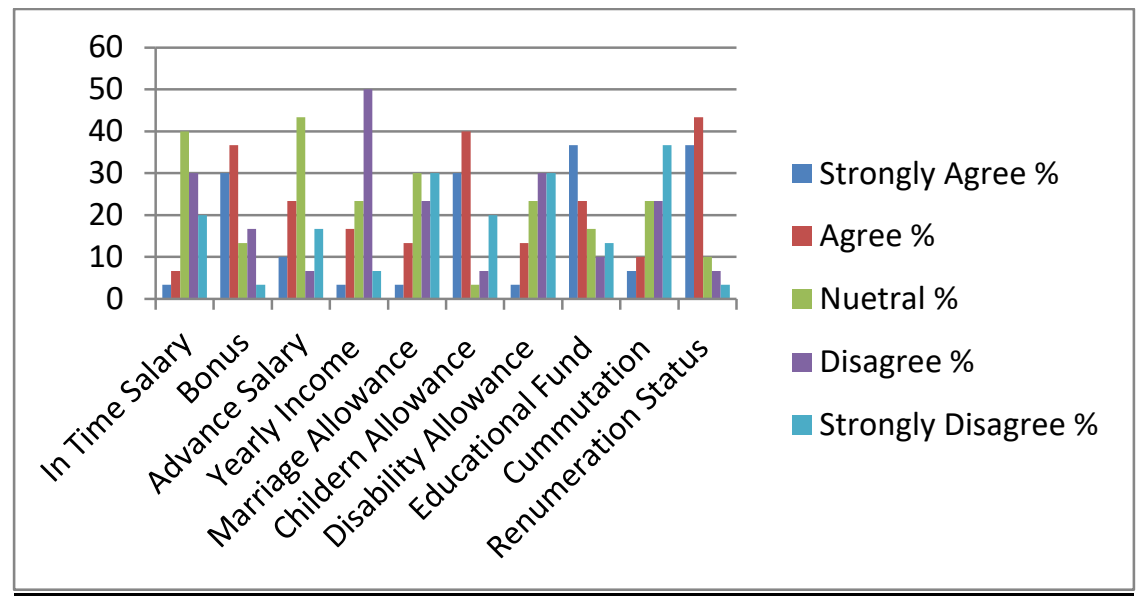

Figure 2 Graph of Non-Financial Rewards in Kohat Textile Mill, Kohat 


\subsection{Provision of Financial Incentives in Janana Textile Mill, Kohat}

Table No 4.3

Analysis of Financial Incentives in Janana Textile Mill, Kohat

\begin{tabular}{|c|c|c|c|c|c|c|c|c|c|}
\hline Statements & SA & $\mathrm{A}$ & & $\mathrm{N}$ & & $\overline{\mathrm{D}}$ & & SD & \\
\hline \multirow[t]{2}{*}{ Salary is given in time every month. } & 2 & 12 & & 4 & & 8 & & 4 & \\
\hline & $6.6 \%$ & 40 & $\%$ & 13.3 & $\%$ & 26.6 & $\%$ & 13.3 & $\%$ \\
\hline \multirow[t]{2}{*}{ Bonus is given to the employees regularly. } & 5 & 16 & & 4 & & 3 & & 2 & \\
\hline & $16.6 \%$ & 53.3 & $\%$ & 13.3 & $\%$ & 10 & $\%$ & 6.6 & $\%$ \\
\hline \multirow[t]{2}{*}{ Advance salaries are easily disbursed. } & 3 & 5 & & 8 & & 7 & & 7 & \\
\hline & $10 \%$ & 16.6 & $\%$ & 26.6 & $\%$ & 23.3 & $\%$ & 23.3 & $\%$ \\
\hline \multirow[t]{2}{*}{$\begin{array}{l}\text { Yearly increment is given to the employees } \\
\text { as per government policy. }\end{array}$} & 1 & 3 & & 2 & & 12 & & 4 & \\
\hline & $4.5 \%$ & 13.6 & $\%$ & 9 & $\%$ & 54.5 & $\%$ & 18.1 & $\%$ \\
\hline \multirow{2}{*}{$\begin{array}{l}\text { Marriage allowance is given to the } \\
\text { employees. }\end{array}$} & 3 & 4 & & 5 & & 7 & & 11 & \\
\hline & $10 \%$ & 13.3 & $\%$ & 16.6 & $\%$ & 23.3 & $\%$ & 36.6 & $\%$ \\
\hline \multirow{2}{*}{$\begin{array}{l}\text { Money is provided to the employees for } \\
\text { the marriage of their children. }\end{array}$} & 3 & 9 & & 4 & & 5 & & 9 & \\
\hline & $10 \%$ & 30 & $\%$ & 13.3 & $\%$ & 16.6 & $\%$ & 30 & $\%$ \\
\hline \multirow{2}{*}{$\begin{array}{l}\text { Appropriate compensation is provided in } \\
\text { case of disability due to accidents. }\end{array}$} & 4 & 3 & & 9 & & 6 & & 8 & \\
\hline & $13.3 \%$ & 10 & $\%$ & 30 & $\%$ & 20 & $\%$ & 26.6 & $\%$ \\
\hline \multirow{2}{*}{$\begin{array}{l}\text { Educational expenditures are provided for } \\
\text { the admission of employees children. }\end{array}$} & 11 & 9 & & 5 & & 3 & & 2 & \\
\hline & $36.6 \%$ & 30 & $\%$ & 16.6 & $\%$ & 10 & $\%$ & 6.6 & $\%$ \\
\hline \multirow{2}{*}{$\begin{array}{l}\text { Employees are provided handsome amount } \\
\text { as commutation at retirement. }\end{array}$} & 2 & 7 & & 3 & & 6 & & 12 & \\
\hline & $6.6 \%$ & 23 & $\%$ & 10 & $\%$ & 20 & $\%$ & 40 & $\%$ \\
\hline \multirow{2}{*}{$\begin{array}{l}\text { Remuneration is given according to the job } \\
\text { level. }\end{array}$} & 3 & 12 & & 5 & & 6 & & 4 & \\
\hline & $10 \%$ & 40 & $\%$ & 16.6 & $\%$ & 20 & $\%$ & 13.3 & $\%$ \\
\hline
\end{tabular}

Table shows that most of the people agree (40\%) that salary is given to the employees each month timely but mostly disagree $(27.67 \%)$ with the statement because of having delay due to some problems at the ends of staff and account section. Employees agreed (53.33\%) for giving annual bonus depending on the production of the mill. Advance salaries are disbursed but most of the people disagree $(23.33 \%)$ that it is given in time. Most of the employees disagreed $(54.55 \%)$ that annual increment is given to the employees. Employees strongly disagreed $(36.67 \%)$ that Marriage allowance is given to them. Most of the people agree $(30 \%)$ that financial aid is given to meet the expenses of their 
children marriages. Most of the people strongly disagreed $(26.67 \%)$ on giving appropriate compensation in case of any disability. In Janana Mill, employees strongly agreed (36.67\%) about the compensation of the children education. At the end of the service, most of the employees strongly disagreed (40\%) about the handsome amount in respect of commutation. Overall, employees agreed (40\%) that remuneration is as per level of the employees' capabilities. This analysis has been explained through the following Graph (Figure 3).

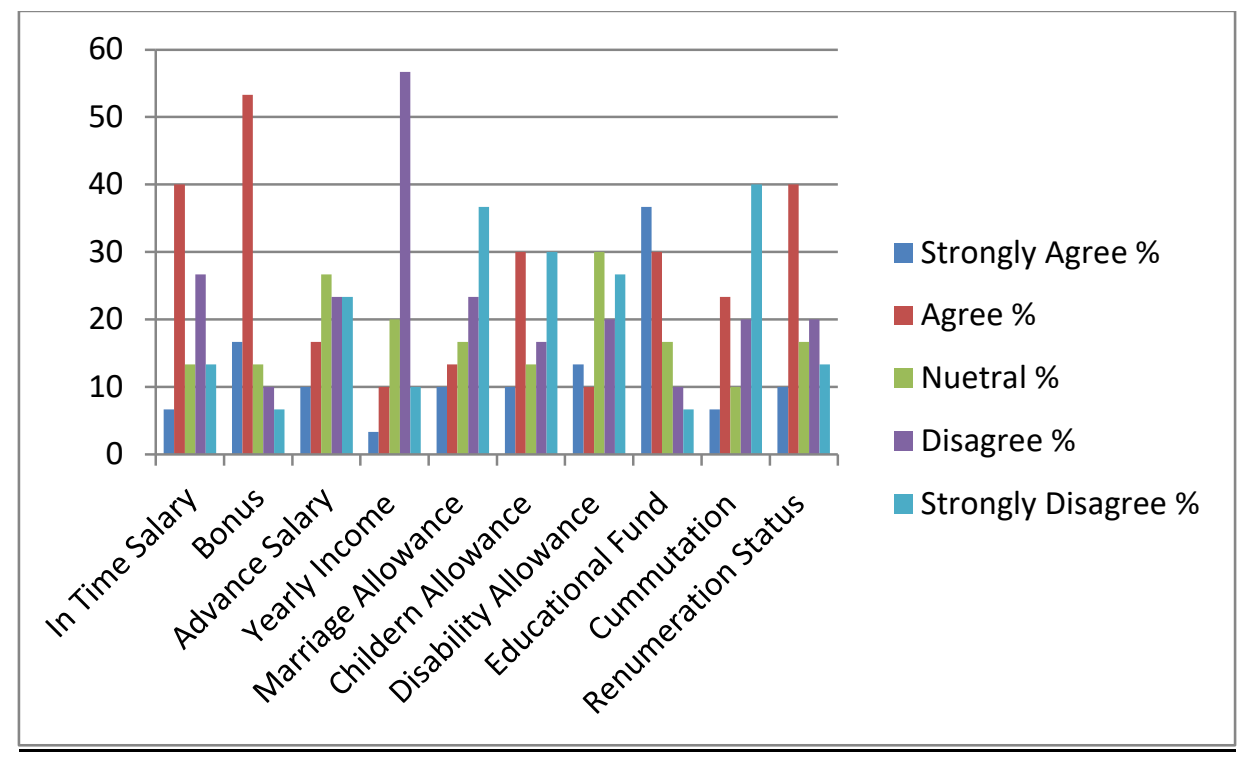

Figure 3. Graph of Financial Rewards in Janana Textile Mill, Kohat 


\subsection{Provision of Non-Financial Incentives in Janana Textile Mill, Kohat}

Table No 4.4

Analysis of Non-Financial Rewards in Janana Textile Mill, Kohat

\begin{tabular}{|c|c|c|c|c|c|c|c|c|c|c|}
\hline Statements & SA & & A & & $\mathrm{N}$ & & D & & SD & \\
\hline \multirow[t]{2}{*}{ Mill has its own hospital. } & 2 & & 3 & & 11 & & 8 & & 6 & \\
\hline & 6.6 & $\%$ & 10 & $\%$ & 36.6 & $\%$ & 26.6 & $\%$ & 20 & $\%$ \\
\hline \multirow{2}{*}{$\begin{array}{l}\text { Mill has its collaboration with any } \\
\text { hospital. }\end{array}$} & 9 & & 8 & & 5 & & 4 & & 4 & \\
\hline & 30 & $\%$ & 26.6 & $\%$ & 16.6 & $\%$ & 13.3 & $\%$ & 13 & $\%$ \\
\hline \multirow{2}{*}{$\begin{array}{l}\text { Transportation facility is provided } \\
\text { to the employees. }\end{array}$} & 2 & & 8 & & 11 & & 4 & & 5 & \\
\hline & 6.6 & $\%$ & 26.6 & $\%$ & 36.6 & $\%$ & 13.3 & $\%$ & 16.6 & $\%$ \\
\hline \multirow{4}{*}{$\begin{array}{l}\text { Appreciation certificates are given } \\
\text { away to the efficient employees } \\
\text { annually. } \\
\text { Hajj quota is available for the } \\
\text { employees. }\end{array}$} & 2 & & 4 & & 5 & & 16 & & 3 & \\
\hline & 6.6 & $\%$ & 13.3 & $\%$ & 16.6 & $\%$ & 53.3 & $\%$ & 10 & $\%$ \\
\hline & 2 & & 5 & & 8 & & 6 & & 9 & \\
\hline & 6.6 & $\%$ & 16.6 & $\%$ & 26.6 & $\%$ & 20 & $\%$ & 30 & $\%$ \\
\hline \multirow{2}{*}{$\begin{array}{l}\text { First aid facilities are provided at } \\
\text { work place. }\end{array}$} & 11 & & 9 & & 2 & & 3 & & 5 & \\
\hline & 36.6 & $\%$ & 30 & $\%$ & 6.6 & $\%$ & 10 & $\%$ & 16.6 & $\%$ \\
\hline \multirow{2}{*}{$\begin{array}{l}\text { Regular medical checkup is done of } \\
\text { the employees and their families. }\end{array}$} & 3 & & 5 & & 8 & & 8 & & 6 & \\
\hline & 10 & $\%$ & 16.6 & $\%$ & 26.6 & $\%$ & 26.6 & $\%$ & 20 & $\%$ \\
\hline \multirow{2}{*}{$\begin{array}{l}\text { Hire and fire policy is not } \\
\text { satisfactory. }\end{array}$} & 12 & & 5 & & 4 & & 6 & & 3 & \\
\hline & 40 & $\%$ & 16.6 & $\%$ & 13.3 & $\%$ & 20 & $\%$ & 10 & $\%$ \\
\hline \multirow{4}{*}{$\begin{array}{l}\text { Basic utilities shops (Cobbler, } \\
\text { washer man, hairdresser and utility } \\
\text { stores) are provided to the } \\
\text { employees. } \\
\text { Proper security arrangement is } \\
\text { made to secure the lives/property of } \\
\text { the employees. }\end{array}$} & 5 & & 2 & & 6 & & 8 & & 9 & \\
\hline & 16.6 & $\%$ & 6.6 & $\%$ & 20 & $\%$ & 26.6 & $\%$ & 30 & $\%$ \\
\hline & 9 & & 15 & & 3 & & 1 & & 2 & \\
\hline & & $\%$ & 50 & $\%$ & 10 & $\%$ & 3.3 & $\%$ & 6.6 & $\%$ \\
\hline
\end{tabular}

Table shows the results regarding Non-Financial rewards given in Janana Textile Mill. There is no particular hospital of this Mill (36.67\%).This Mill has collaboration with the other hospitals (30\%), where, treatment is allowed for the employees (36.67\%). Employees are not much familiar with the transportation facility (36.67\%). Appreciation certificates are not given to the employees $(53.33 \%)$. People are disagreed regarding Hajj Quota for the employees (30\%). Employees strongly agreed that First Aid facilities are available in the Mill $(36.67 \%)$. Facility of regular medical checkup is not been provided to the employees and their family (26.67\%). Hiring facility is available for the 
employees (40\%). All basic facilities to the employees including Cobbler, washer man, Hairdresser and utility stores inside the vicinity of the Mill are not as per need of the employees (30\%). Mill has well security arrangement (50\%). Overall analysis of the Non-Financial rewards has been given through the following Graph (Figure No 4).

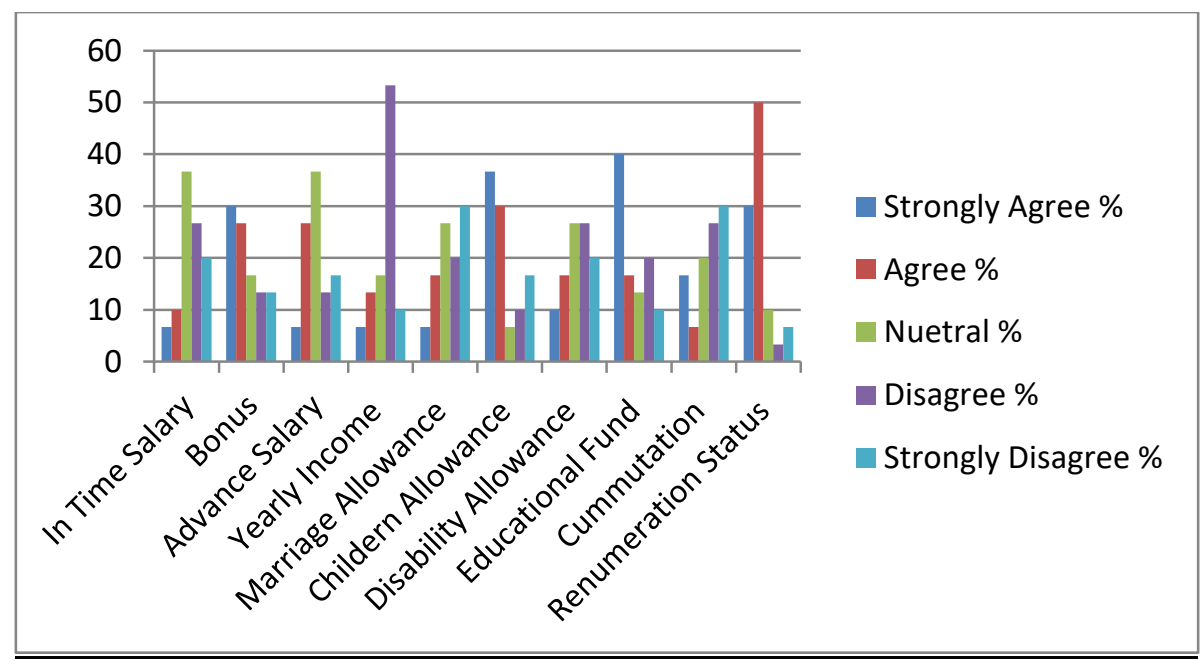

Figure 4 Graph of Non - Financial Rewards in Janana Textile Mill, Kohat

\subsection{Comparison of Financial Incentives between Kohat Textile Mill and Janana Textile Mill}

Analysis of comparison regarding Financial Rewards between Kohat Textile Mill and Janana Textile Mill shows that almost salary is given to the employees timely but it gets delays in Janana Textile Mill (Mean=3.00) as compared to the Kohat Textile Mill. Most of the people are getting bonus depending upon the production of the Mill but it is less practice in Janana Textile Mill (Mean=3.20). Employees are not so much satisfied for getting their advanced salaries almost in both mills. Yearly increment is given to each employees but most of the employees do not agree on this statement where people of Janana Mill are less satisfied (Mean=2.32). Marriage allowance is given but employees are less satisfied in Janana Mill (Mean=2.37) as compared to the Kohat Textile Mill. In Kohat Textile Mill, people are given their children allowance for the marriage of their children (Mean=3.03) as compared to the Janana Textile Mill (Mean=2.63). Janana Mill take extra care for giving disability allowance to their employees $(\mathrm{Mean}=2.63)$ as compared to the Kohat Textile Mill (Mean=2.43). Fund for children education of the working people are 
given more in Kohat Textile Mill (Mean=3.97) as compared to the Janana Textile Mill (Mean=3.80). Commutation is always provided to the people timely in Kohat Textile Mill (Mean=2.5) as compared to the Janana Textile Mill (Mean=2.37) which is very low in both mills. In both mills remuneration is almost has equal status but it is comparatively less in Janana Textile Mill $($ Mean=3.13) as compared to the Kohat Textile Mill (Mean=3.50).

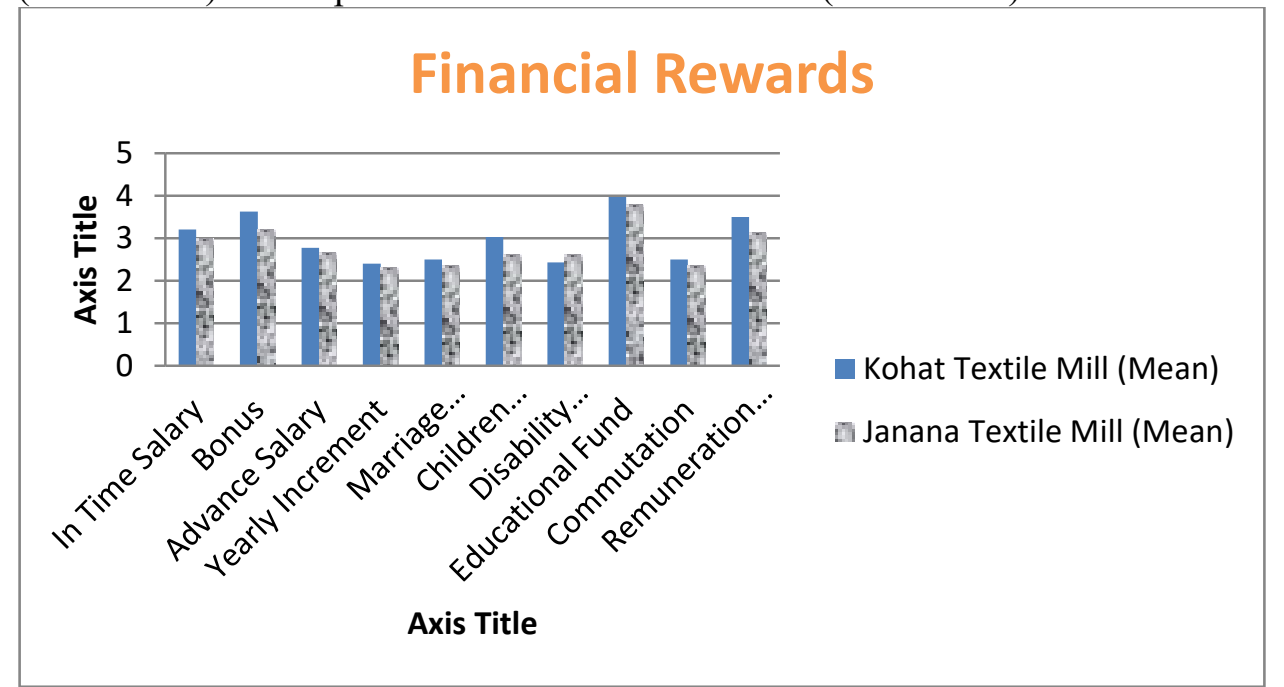

Figure 5 Mean Comparison of Financial Rewards between Kohat Textile Mill \& Janana Textile Mill, Kohat

\subsection{Comparison of Non-Financial Incentives between Kohat Textile Mill and Janana Textile Mill}

Analysis regarding Non-Financial rewards between Kohat Textile Mill and Janana Textile Mill shows that both mills have no such hospital which may be claimed that this is on the ownership of the hospital. Both mills have good collaboration with the other hospitals as shown by the analysis of Kohat Textile Mill (Mean=3.60) and Janana Textile Mill (Mean=3.50). Transport facility in Janana Textile Mill (Mean=2.60) is not much better as compared to the Kohat Textile Mill (Mean=3.23). Employees are given appreciation on doing their good job which is better in Kohat Textile Mill (Mean=3.83) as compared to the Janana Textile Mill (Mean=3.60). Administration of the mills are not paying their good attention for paying Hajj quota to the employees, although Janana Textile mill is working more (Mean=3.17) as compared to the Kohat Textile Mill (Mean=2.97). First aid facility is more reliable in Janana Textile mill (Mean=4.2) as compared to the Kohat Textile Mill (Mean=3.93). Medical facility is not appropriate in both 
mills which ultimately affect the people and their families. Hire and fire policy in both mills is almost equal as in Kohat Textile Mill (Mean=3.80) and in Janana Textile Mill (Mean=3.77). Basic utility shops to provide the basic needs of the life both mills have the same status (Mean=3.73). Security arrangement in both mills is very good but Kohat Textile Mill $($ Mean=4.27) is overall better than Janana Textile Mill (Mean=4.17).

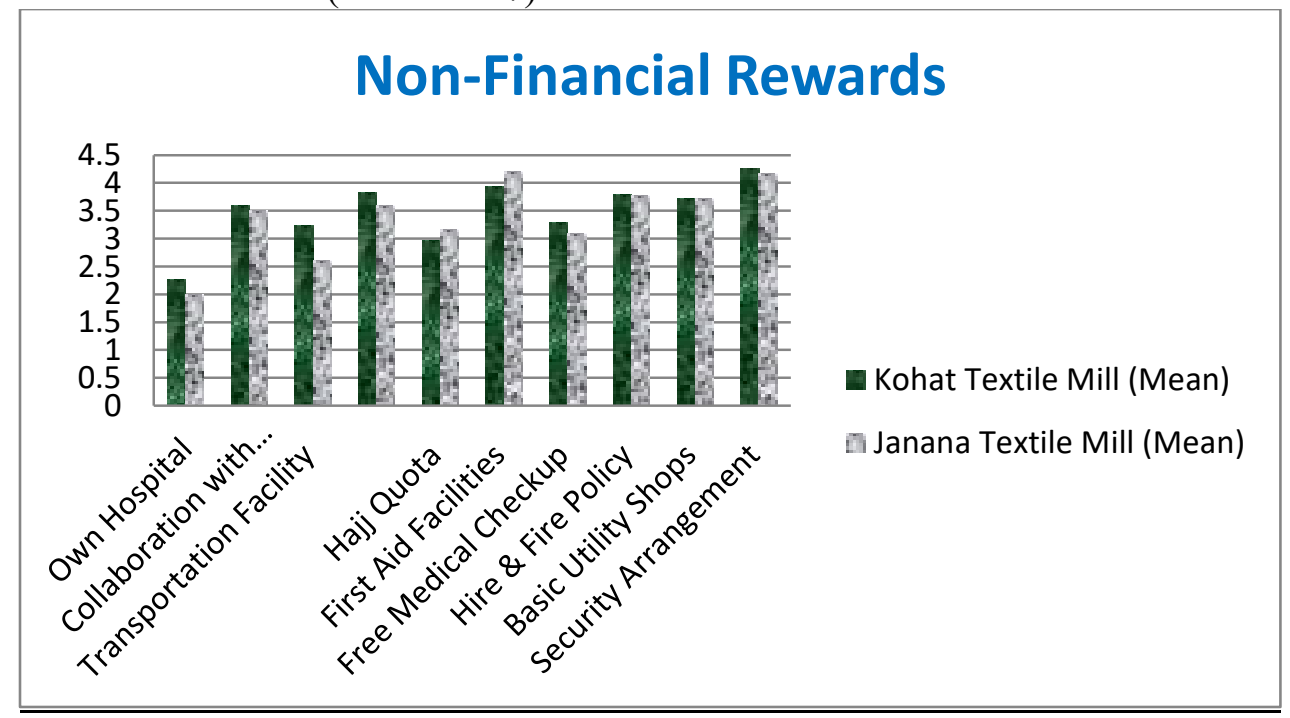

Figure 6 Mean Comparison of Non-Financial Rewards between Kohat Textile Mill \& Janana Textile Mill, Kohat

\section{Discussion}

The major focus of this research study was to find the impact of financial and non-financial rewards considered under incentives which may be given to the employees working in the different industries in general and particularly in textiles mills. The study was important in the sense that financial and nonfinancial rewards plays very important role in the production of the organization or any industry and many causes arise due to not paying attentions on it like low engagements in work area, less productive as compared to others, as identified and explained by the Willis Towers Watson Global Benefits Attitude Survey in 2017 (Nyce, 2017).

Comparison of the financial rewards between Kohat Textile Mill and Janana Textile Mill explored that job performance affect the attitude of the employees in case of delay into their salaries. Bonuses are not defined which is an attractive incentive for the employees to increase the production of the mills. 
The employees remain unsatisfied in getting their advanced salaries that reflect that this practice is not so much carried out to increase the job performance of the employees. Yearly income was also a factor that contribute in job performance which was not addressed in the mills. Marriage allowances were there but there were difficult procedures which becomes hurdle in increasing the job performance (Saqib, Abrar, Muhammad Sabir, Bashir \& Ahmad Baig, 2015).

Comparison on the basis of non-financial incentives, it was observed that mills have affiliation with the hospitals but they do not have their own hospitals as the other organizations have like $\mathrm{CMH}$, PAF Hospitals, Navel Hospitals, hospitals of Atomic Energy Commission etc. government has no interest in such industries which may increase the job performance of the employees. General facilities like Hajj quota, funds for children education and employment for the wards were main problems explored in the study. This field was lacking in hiring and housing facilities also (Yousaf, Latif, Aslam \& Saddiqui, 2014).

\section{Conclusions}

In the light of the analysis of data and findings of the study following conclusions were drawn.

1. Many respondents mentioned that advance salaries were easily disbursed and yearly increment was also given but majority of the disagreed that support was provide for marriage arrangements of their children. Moreover, expenditures were not provided for the admission of employees children

2. Appropriate compensation was provided to employees in case of disability due to accidents and medical facilities were provided. However, regular medical checkups were not done of the employees and their families.

3. Employees were provided handsome amount as commutation on retirement and remuneration was also given according to the job level.

4. Appreciation certificates were given away to the efficient employees annually. Hajj quota was also available for the employees but need attention to have review Hajj policy.

5. Most of the respondents mentioned that hire and fire policy was not satisfactory and insurance of every worker was done.

\section{Recommendations}

Above results lead to the under mentioned recommendations;

1. Keeping in view of the marriage allowances for daughters, it is suggested that Textiles Mills may be provided some support from the government for employees and their children. This would have a positive effect on employees.

2. Education build the nation, and it has significant role for the masses who are much concerned about education of their children so it is recommended that 
educational expenditures may be provided for the admission of employees children. Quotas may also be allocated in universities and colleges for the employees' children.

3. Regular medical checkup of the employees and their families may be ensured in associated hospitals or special medical allowance may be given to the employees.

4. Better working conditions and secure environment are the right of every worker so it is recommended that availability of the safety gadgets to the employees must be ensured and proper timing may be observed for their working.

\section{References}

Asif, S. D. (2007). Textile Sector is the backbone of Pakistan's economy. The ills faced by the sector and its contribution towards economic development. Syndicate, FBR Pakistan.

Azhar, S., \& Batool, S. M., (2004). Education and the HR Challenge, Human Resource Development Network. p.3-5

Basta, S., Soekirman, Karyadi, D., \& Scrimshaw, N. (1979). Iron deficiency anemia and the productivity of adult males in Indonesia. The American Journal of Clinical Nutrition, 32(4), 916-925. doi: 10.1093/ajen/32.4.916

García-Bernal, J., Gargallo-Castel, A., Marzo-Navarro, M., \& Rivera-Torres, P. (2005). Job satisfaction: empirical evidence of gender differences. Women in Management Review, 20(4), 279-288. doi: 10.1108/09649420510599098

Chen, S., Yang, C., Shiau, J., \& Wang, H. (2006). The development of an employee satisfaction model for higher education. The TQM Magazine, 18(5), 484-500. doi: 10.1108/09544780610685467

Cranny, C., Smith, P., \& Stone, E. (1992). Job Satisfaction. New York: Lexington Books.

Fashoyin, T., (1997). Labour Relations and Productivity Enterprise and Management Development, Working Paper EMD/18/E, Enterprise Development Department. 
Greasley, K., Bryman, A., Dainty, A., Price, A., Soetanto, R., \& King, N. (2005). Employee perceptions of empowerment. Employee Relations, 27(4), 354368. doi: $10.1108 / 01425450510605697$

Group, M. (2011, September). Retrieved 2013, from shrm: http:// www.s hrm.org/hrdisciplines/ compensation/ articles/ pages/ noncashmotivator.aspx

Lund, D. B. (2003). Organizational culture and job satisfaction. Journal of Business and Industrial Marketing, 18(3), 219-236.

Ministry of Finance, Government of Pakistan. (2009). Economic survey of Pakistan 2008-2009. Retrieved September 22, 2009, from, http://www.accountancy.com.pk/docs/economic-survey- of-pakistan2008-09.pdf

Nyce, S. (2017, Nov 17). Willis Towers Watson. Retrieved from https://www.willistowerswatson.com/en/insights/2017/11/2017-globalbenefits-attitudes-survey

Rehman, A. U. (2008). Constraints in the Evaluation of HRD Interventions. NUML Journal of Management and Technology,1, 138-158.

Saqib, S., Abrar, M., Muhammad Sabir, H., Bashir, M., \& Ahmad Baig, S. (2015). Impact of Tangible and Intangible Rewards on Organizational Commitment: Evidence from the Textile Sector of Pakistan. American Journal of Industrial And Business Management, 05(03), 138-147. doi: 10.4236/ajibm.2015.53015

Tausif, M. (2012). Influence of Non-Financial Rewards on Job Satisfaction: A Case Study of Educational Sector of Pakistan. Asian Journal of Management Research, 2(2).

Teti, E., \& Andriotto, M. (2013). Effectiveness of employee welfare schemes: differences of specific professional profiles. The International Journal of Human Resource Management, 24(17), 3232-3246. doi: $10.1080 / 09585192.2013 .763840$

World Bank, (1991). World Development report, New York: Oxford University Press Retrieved on July 22, 2008 from http://www- 
wds.worldbank.org/external/default/ DSContentServer/ IW3P/ IB/ 1998/ 11/17/000009265 3981005112648/ Rendered/PDF/ multi0page.pdf

Yousaf, S., Latif, M., Aslam, S., \& Saddiqui, A. (2014). Impact of financial and non-financial rewards on employee motivation. Middle-East journal of scientific research, 21(10), 1776-1786.

Zaidi, S. A., (2006). Introduction: The Context of Globalization in Pakistan. In: A. Sabina \& S. A. Zaidi. (Eds), Education under Globalization: The Case of Pakistan (pp. 1-11). Pakistan, Actionaid. 